\title{
Okul Yöneticilerinin Kuantum Liderlik Davranışları ve Öğretmenlerin Yaratıcı Düşünme Eğilimleri Arasındaki İlişkinin İncelenmesi
}

\author{
DOI: 10.26466/opus. 886390
}

\author{
* \\ Münevver Çetin * - Hilal Gürkan ${ }^{* *}$ \\ * Prof. Dr., Marmara Üniversitesi, Eğitim Bilimleri, İstanbul/Türkiye \\ E-Posta: munevverolcum@gmail.com ORCID: $\quad \underline{0000-0002-1203-9098}$ \\ ** Öğretmen, MEB, İstanbul/Türkiye \\ E-Posta: hilalgurkan@hotmail.com ORCID: $\quad$ 0000-0002-6719-8440
}

Öz

Bu çalışmada, okul yöneticilerinin kuantum liderlik davranışları ve öğretmenlerin yaratıcı düşünme eğilimleri arasındaki ilişki incelenmiştir. Araştırma ilişkisel tarama modeline göre desenlenmiştir. Araştırmada "Okul Yöneticilerinin Kuantum Liderlik Davranışları Ölçeği" ve "Marmara Yaratıcı Düşünme Ĕ̆gilimi Ölçeği" kullanılmıştır. Çalışmaya İstanbul ilinden çeşitli kademelerde ve branşlarda görev yapan 284 öğretmen katılmıştır. Verilerin analizinde betimsel istatistikler, $t$-testi ve tek yönlü varyans (ANOVA) ve pearson korelasyon analizi kullanılmıştır. Araştırma bulgularında, okul yöneticileri kuantum liderlik davranışın çoğu zaman göstermektedir. Okul yöneticilerinin kuantum liderlik davranışları öğretmenlerin cinsiyet, yaş, çalıştıkları okul kademesi, mezuniyet, okulda çalışma süreleri, okul müdürleri ile çalışma süreleri değişkenlerine göre anlamlı bir farklllık göstermemektedir. Öğretmenler genellikle yaratıcı düşünme eğilimi göstermektedirler. Yaratıcı düşünme eğilimleri bakımından yenilik arama alt boyutunda ilkokulda çalışan öğretmenlerin yüksek puana, cesaret alt boyutunda ise ortaokulda çalışanların düşük puana sahip olduğu görülmüştür. Okuldaki çalışma süresi 11 yıl ve üzeri olan öğretmenlerin öz disiplin puanları yüksek, okul müdürü ile çalışma süresi 5 yıl ve üzeri olanlarn cesaret puanları daha yüksek bulunmuştur. Kuantum liderlik ile yaratıcı düşünme eğilimlerinin bazı boyutları arasında pozitif yönde anlamlı ilişkiler bulunmuştur. Eğitim örgütlerinin açık sistem özelliğine sahip olmaları yapısındaki karmaşıklı̆̆ı arttırmaktadır. Öğretmenlerin yaratıcı düşünme eğilimleri desteklenerek örgütün kaotik durumlardan çıkması ve belirsizliklerin firsata dönüştürülmesi için kuantum liderlik bir yol gösterici olarak önerilebilir.

Anahtar Kelimeler: Kuantum Liderlik, Yaratıcı Düşünme Eğilimi, Liderlik. 


\title{
Investigation of the Relationship between School Administrators' Quantum Leadership Behaviors and Teachers' Creative Thinking Tendencies
}

*

\begin{abstract}
In this study, the effect of quantum leadership levels of school administrators on creative thinking dispositions of teachers was examined. "Quantum Leadership Behavior Scale of School Administrators" and "Marmara Creative Thinking Disposition Scale" were used in the study. 284 teachers working at various levels and branches in Istanbul participated in the study, in which the relational scanning model was used. Descriptive statistics, $t$-test, one-way variance (ANOVA) and Pearson correlation analysis were used to analyze the data. In the findings of the research, school administrators often show quantum leadership behavior. Quantum leadership behaviors of school administrators do not show a significant difference according to the variables of teachers' gender, age, school level they work, graduation, working time at school, and working time with school principals. Teachers generally tend to think creatively. Significant positive relationships were found between quantum leadership and some dimensions of creative thinking dispositions. Quantum leadership can be suggested as a guide for the organization to get out of chaotic situations and transform uncertainties into opportunities by supporting teachers' creative thinking dispositions.
\end{abstract}

Key Words: Quantum Leadership, Creative Thinking Tendency, Leadership in Education. 


\section{Giriş}

Fizikte, Galileo ve Newton temel bilimsel yöntemleri ortaya koymuşlardır. Temel bilimlerdeki bu gelişmeler sosyal alanlara da yansımıştır. Yönetim alanında öncü sayılan Taylor, Weber ve Fayol pozitivist bilimde kullanılan deney, gözlem ve parçalara ayırma gibi yöntemleri örgüt ve yönetim biliminde uygulamışlardır. Taylor, örgütün parçalardan meydana geldiğini, bu parçaların ise merkezi bir otorite tarafından yönetilerek yönetsel davranışların sonuçlarının tahmin veya kontrol edilebileceğini ileri sürmüştür (Uzunçarşıll Soydaş, 2012). Bu yönetim düşüncesinde örgütler, kapalı bir sistem ve çevresel faktörlerden bağımsız işleyen bir dünya olarak görülmüş, yalıtılmış bir dünya olarak ele almıştır. Aynı nedenler aynı sonuçları doğurur deterministlik görüşüne göre düzenli bir dünyanın olduğu varsayılmıştır (Erçetin, 2001).

Wheatley (2006)'e göre hiyerarşik bir yapıları olan, otorite ve denetim her düzeyde hissedildiği, bürokratik yapıya sahip, her işlem için belirlenmiş kuralları bulunan, basit sebep sonuç ilişkisi anlayışına sahip Newton örgüt tipine göre örgütler artık yönetilemezler (Overman, 1996; Tetenbaum,1998; Deardorff ve Williams, 2006). Liderler örgütlerini yeni bilimin önem kazanmasıyla ancak kuantum fiziğinin bakış açları ile yeniden oluşturabilirler.

Kuantum yönetim dünyası farklı noktalara odaklanmaktadır. Bu yönetim anlayışında madde yerine enerjiye, oluş yerine gelişmeye, sebepler yerine rastlantılara ve determinizm anlayışı yerine yapısalcılığa ve farkındalık düzeylerine odaklanılır (Overman, 1996). Pek çok açıdan değerlendirildiğinde, kuantum yönetim, örgütün yapısal işlevleri yerine daha çok örgütün ruhsal niteliklerini ve yaşamsal özelliklerini öne çıkaran bir bakış açısı geliştirir. Bu bakış açısı Shelton ve Darling (2004)'in de belirttiği gibi örgütleri insan temelli sistemler olarak kabul etmektedir ve kuantum becerileri olduğunu savunmaktadırlar. Kuantum becerileri modeli, altı beceri ve modelin ortasında yer alan bir beceriden oluşur. Kuantum görüş (Quantum seeing), Kuantum düşünüş (quantum thinking) ve Kuantum hissediş (quantum feeling) psikolojik becerilerdir. Kuantum bilinç (quantum knowing), kuantum davranış (quantum acting) ve kuantum güven (quantum trusting) ise ruhsal becerilerdir (Shelton ve Darling, 2004). 
Eğitim örgütleri diğer örgütler ile karşılaştırıldığında daha çok gelişmeye ve öğrenmeye açı örgütler olmaları beklenmektedir (Yavaş ve Polat, 2013). Bu durum eğitim liderinin yetiştirilmesinde farklı bakış açılarının geliştirilmesine neden olacaktır. Çünkü okullar sadece örgüt özelliklerini taşımazlar aynı zamanda toplumun özelliklerini de yansıtan kurumlardır (Şişman ve Turan, 2002). Eğitim sisteminde okullarımızı birer sosyal sistem olarak düşündüğümüzde değişen şartlara uyum sağlamları gerekmektedir. Okul yöneticisi yeni duruma yön verecek kişi olacaktır. Eğitim sistemlerindeki yeni yapısal ve davranış değişikliğindeki gereklilikler eğitim lideri olarak okul yöneticiliğini tartışmaya açmaktadır. Eğitim yöneticisinin eğitimle ilgili tüm paydaşlara gerek öğretmen gerekse öğrencilere veya yönetime katılan bireylere bütünsel bir çerçeveden bakmasını gerektirmektedir (Erçetin, 1999).

Eğitim örgütleri karmaşık sistemlerdir (Dean, 1995). Bu karmaşıklık amaçlar, kaynaklar, ilişkili olduğu etkenler açısından ve okul öncesi, ilköğretim, ortaöğretim ve yükseköğretim kurumları arasındaki ilişkilerde de geçerlidir. Bu açıdan örgütsel öğrenmenin, doğal bir örgütsel ruha sahip davranışları içeren kuantum örgütlerde geleceğin eğitim kurumları ve diğer örgütsel yapıların oluşumunda büyük katkı sunabilecek bir kavram olarak ortaya çıkması düşünülmektedir (Yavaş ve Polat, 2013).

Erçetin (2000, s.77) Blank 'in kuantum fiziği ve klasik fizik farklılıklarına dayandırdığı kuantum liderliğini 5 boyutta ele almaktadır: Kuantum Fiziği Varsayımı Parça-Dalga İkilemi

Belirsizlik ve Olasılıklar Enerjinin Kesikliliği Kuantum Liderlik Varsayımı Liderlik, Lider-İzleyenler İkileminde Bir Etkileşim Alanıdır

Kuvvetin Belli Bir Yere KadarLiderliğin Etkisi Etkileşime Dayalıdır Uygulanması

Kuantum kuramının parçacık-dalga ikilemi, bir bütünü oluşturan parçalar olarak yorumlanması önemlidir. Çünkü aynı anda bir bütünün farklı yönleri olarak dalga ve parça olma özelliği tamamlayıcılık ilkesidir (Ertürk Kayman, 2008). Farklı kişisel özelliklerine sahip kişiler bir araya geldiğinde farklılıkların doğal karşılandığı ve benimsendiği ortak amaçları gerçekleştirmek adına takım ruhu ile hareket etmek kuantum 
örgütlerinde önemlidir. Her bir kişinin tarzı ve düşünüş biçimi bir diğerinin yargılarını dengeleyecektir. Okul örgütlerini göz önüne aldığımızda okul müdürü, müdür yardımcları, öğretmenler ve okul personeli öğrenciler ve okul çevresi ile ilişkili olan diğer çevresel faktörler bir bütünün birbirinden ayrı değerlendirilmeyecek parçaları olarak düşünülebilir. Birbirinden etkilenen parçalardan oluşan okul örgütleri, bu durumda, değişime açık ve esnek olmalıdırlar.

Kuantum liderler eğitim yöneticileridir. Eğitim yöneticilerinin izleyenleri de sistemdeki görevli personel, öğrenciler, veliler olarak düşünülmelidir (Ertürk Kayman, 2008). Eğitim yöneticileri eğitim kurumlarının genel resmini görebilmeli, atacakları adımlarda veya verecekleri kararlardan doğacak olası sorunları kestirebilmelidirler.

Karmaşık birer örgüt olan eğitim kurumlarında okul yöneticilerinin bütüncül ve dikkatli adım atma gayretlerine rağmen her zaman belirsizlikler ortadan kaldırılamaz. Kaos durumunda liderlik yapılandırılamaz ve kestirilemez. Kestirilemeyen durumlarda, kuantum lider olarak okul yöneticisinden tartışmaya açık olan, ayrım yapmayan, gelişime açık, belirsiz durumları arzu edilen ve beklenen olarak gören, kendi insiyatiflerini geliştiren, kendini gerçekleştirmeye çalışan daha esnek ve tarafsız bilgiden yana olan davranışlar beklenmelidir (Clampitt, Williams ve Korenak, 2000).

Kuantum liderlik paradigmasında liderlik, değişebilir ve değiştirilebilir bir olgudur. Bu olgu, kuantum liderliğin kesikliliği ilkesidir. Liderler ve izleyenler değişik zaman dilimlerinde ya da durumlarda, kendiliğinden gelişen bir durum bağlamında bir araya gelebilir, bazı nedenlerle ayrılabilir, lider kendine yeni izleyenler bulabilir veya izleyenlerden başka bir lider çıkmasını kabul edip onun etrafında birleşebilirler (Erçetin, 2000, s.79).

Etkileşimin niteliği ve etkileşime yüklenen anlam "Liderliğin Etkisi Etkileşime Dayalıdır" ilkesini belirlemektedir. Liderin izleyenlerle ve potansiyel izleyenleri ile ve çevresiyle olan karşılıklı ilişkileri ve etkileşimi onun lider olarak algılanması üzerinde de etkili olmaktadır. Açık, paylaşılan bir vizyon oluşturan ve birliktelik ruhu etrafında izleyenlerini birleştirebilen liderin etkisinin daha uzun olacağı düşünülebilir.

Okul içindeki etkileşim süreci aynı zamanda örgütsel öğrenmeye kapı aralamaktadır. Sorunlar karşısında atılacak adımlar, alınacak kararlar ve 
izlenecek stratejiler birlikte kararlaştırılır. Hatalardan dersler çıkarılır. Liderliğini etkisi etkileşimin derecesine, kalitesine göre daha da artabilir. Etkili bir okul oluşturabilmek için okul yöneticisi personelini ve paydaşlarını etkililiği yönünde etkilemeli veya model olmalıdır (Ertürk Kayman, 2008).

$\mathrm{Bu}$ gerçekler göz önünde bulundurulduğunda, liderin etkisi ve etkililiğinin sürdürebilmesi için bağıntılılık, karmaşıklık ve bölünmez bütünlük kavramlarının dikkate alınması ve liderlik felsefesini yeniden şekillendirilmesine gereksinim vardır. Bu kavramların bazıları eğitim örgütlerini de etkilemekte ve değiştirmektedir. Katılımcı okul tabanlı yönetim, meslektaşlar arası işbirliği, öğretmenlerin yetkilendirilmesi, grup öğretimi, disiplinler arası program geliştirme ve işbirlikçi öğrenme yaklaşımı (Ertürk Kayman, 2008) bu anlamda liderliğin kesikliliğini ve liderin kendisine odaklanılmasından farklı olarak birlikte liderlik anlayışına doğru yaklaşımın gereğine işaret etmektedir. Lider baskılayan, yargılayan zorlayan kişi değil izleyenlerine danışmanlık yapan, yol gösteren onlara katkı sunan kişi (Deming, 1996) olarak görülmelidir. Liderliğin gücü ve yetkisi bu yolla artacak, izleyenleri üzerinde olumlu yansımaları olacaktır. Liderliğini paylaşılması aynı zamanda izleyenin örgütle özdeşleşme duygusunun gelişmesine ortam hazırlayacaktır.

Kuantum örgütlerde, liderin görevinin yönetmekten çok kendi kendine örgütlenme için ortam hazırlama olduğuna vurgu yapılmaktadır (Wheatley, 2006). İzleyenlerin ilgi ve gereksinimlerini gözetilmediği, karar alma sürecinde yer edilmediği ve paylaşımların oldukça kısıtlandığı böyle durumlarda liderin etkisi düşük bir düzeyde kalacaktır.

Karmaşıklık, kaotik durumlar ve belirsizliğin yoğun olarak hissedildiği durumlarda esnek ve etkileşimli bir lider gereksinimini ortaya çıkarmaktadır. Esneklik, örgüt yöneticilerinin zaman zaman daha önce verilmiş kararlarını, değişim karşısında esnetebilmeleridir. Çünkü örgütler her zaman belli kurallarla yönetilemz. Kuramlar ve uygulamalar zaman ve durumun gereklerine göre esneyebilecek özellikle olmadır. Çünkü çevrenin hızlı değişimi süreçlerde de hızlanmaya ve değişmeyi getirmektedir (Keskinkılıç Kara, 2013)

Günümüzde örgütler rekabet avantajı elde etmek ve varlıklarını sürdürmek için orijinal fikirler ortaya koymak zorundadırlar. Ancak yeni ve farklı fikirlerin tetiklediği tasarımlarla yenidünya düzenine ayak 
uydurabilmektedirler. Bunu sağlayacak olan yaratıcı düşünme eğilimi olan ve yaratıcı düşünen bireylerdir (Burkus, 2014; Özgenel ve Çetin, 2017). Korucu ve Olpak (2015) tarafından yaratıcı düşünme; karmaşıklık yönetimi, merak, özyönetim, yaratıcıllk, risk alma, üst düzey düşünme ve mantıksal akıl yürütme becerileri, orijinal fikirleri ifade etmek olarak tanımlanmıştır. Literatüre göre yaratıcı bireylerin özellikleri; farklı fikirler üretebilen, hata yapmaktan korkmayan, risk alan, merak eden, olaylara farklı açılardan bakabilen bireyler (Doğan, 2016) olan kişilerdir.

21.y.y. yeterlikleri arasında yer alan yaratıcı düşünme becerisi Milli Eğitim Bakanlığı tarafından yayımlanan öğretim programında alana özgü temel becerilerden biridir (MEB,2018). Bu nedenle öğretmenlerin eğitimöğretim ortamlarını yenilikçi, yaratıcı ve üst düzey düşünme becerilerini kazandırıcı şekilde düzenlemelerinin önemini ortaya koymaktadır. Olaylara farklı açlardan bakan, yenilikçi çözüm üreten, çok yönlü, yeni durumlara kolay uyum sağlayan bireylerin yetiştirilmesi (Kozikoğlu ve Küçük, 2020) ve öğrencilerin yaratıcı potansiyellerini kullanmaları öğretmenlerin de yaratıcı düşünme potansiyellerinin geliştirilmesi (Orhan, 2014) ve yaratıcı düşünme eğilimlerini ortaya koymanın önemini göstermektedir.

Eğitim örgütlerinin açık sistem özelliğine sahip olmaları yapısındaki karmaşıklığı arttırmaktadır. Okullardaki yaratıcı düşünme eğilimleri desteklenerek örgütün kaotik durumlardan çıkması ve belirsizliklerin fırsata dönüştürmesi için kuantum liderlik önemli görülmektedir.

\section{Araştırmanın Amacı}

$\mathrm{Bu}$ araştırmanın amacı "öğretmen görüşlerine göre okul yöneticilerinin kuantum liderlik davranışları ile öğretmenlerin yaratıcı düşünme eğilimleri arasındaki ilişkilerin" belirlenmesidir. Bu doğrultuda aşağıdaki sorulara cevap aranmıştır:

1. Okul yöneticilerinin kuantum liderlik davranışları hangi düzeydedir?

2. Öğretmen görüşlerine göre okul yöneticilerinin kuantum liderlik davranışları öğretmenlerin cinsiyet, yaş, çalıştıkları okul türü, kıdem, mevcut okul müdürü ile çalışma süresi değişkenlerine göre anlamlı şekilde farklılaşmakta mıdır? 
3. Öğretmenlerin yaratıcı düşünme eğilimleri hangi düzeydedir?

4. Öğretmenlerin yaratıcı düşünme eğilimleri düzeyleri öğretmenlerin cinsiyet, yaş, çalıştıkları okul türü, kıdem, mevcut okul müdürü ile çalışma süresi değişkenlerine göre anlamlı şekilde farklılaşmakta mıdır?

5. Okul yöneticilerinin kuantum liderlik düzeyleri ile öğretmenlerin yaratıcı düşünme eğilimleri arasında anlamlı ilişki var mıdır?

\section{Araștırmanın Önemi}

Yönetim bilimine yeni ve farklı bir anlayış kazandıran kuantum liderlik davranışlarının örgütün yaratıcı düşünme eğilimleri üzerinde etkileri olabileceği noktasından hareketle bu araştırmada eğitim örgütleri özelinde bu kavramlar arasındaki ilişkilere odaklanılacaktır. Literatür tarandığında okul yöneticilerinin kuantum liderlik düzeyleri ile öğretmenlerin yaratıcı düşünme eğilimleri arasındaki ilişkileri inceleyen çalışmaya rastlanmamıştır.

\section{Yöntem}

\section{Araştırmanın Modeli}

$\mathrm{Bu}$ çalışmada, öğretmen algılarına göre okul yöneticilerinin kuantum liderlik davranışları ile öğretmenlerin yaratıcı düşünme eğilimleri arasındaki ilişki incelenmiştir. Araştırmada ilişkisel tarama modeli kullanılmıştır. İlişkisel tarama modeli; "iki ya da daha fazla değişken arasında birlikte değişim varlığını ve/veya derecesini belirleyen” (Karasar, 2007) araştırma modelidir.

\section{Evren Örneklem}

Çalışmaya 2018-2019 eğitim öğretim yılında İstanbul İli Beykoz İlçesi devlet okullarında çeşitli kademelerde ve branşlarda görev yapan yaklaşık 1200 öğretmenden basit tesadüfî örnekleme yöntemi ile seçilen 284 öğretmen katılmıştır. 
Tablo 1. Öğretmenlerin Demografik Özelliklerinin Frekans ve Yüzde Değerleri

\begin{tabular}{llll}
\hline & Gruplar & $f$ & $\%$ \\
\hline Cinsiyet & Kadın & 183 & 64,4 \\
& Erkek & 101 & 35,6 \\
\hline Yaş & 31 yaş ve altı & 90 & 31,7 \\
& 32-37 yaş & 83 & 29,2 \\
& 38-43 yaş & 53 & 18,7 \\
& 44 yaş ve üzeri & 58 & 20,4 \\
\hline Okul Kademesi & İlkokul & 60 & 21,1 \\
& Ortaokul & 81 & 28,5 \\
& Lise & 143 & 50,4 \\
\hline Mezuniyet & Lisans & 225 & 79,2 \\
& Yüksek Lisans & 59 & 20,8 \\
\hline Okuldaki Görev & 1-5 yıl & 181 & 63,7 \\
Süresi & 6-10 yıl & 70 & 24,6 \\
& 11 yıl ve üzeri & 33 & 11,6 \\
\hline Mevcut Müdürle & 1 ylldan az & 74 & 26,1 \\
Çalışma Süresi & 1-2 yıl & 89 & 31,3 \\
& 3-4 yll & 90 & 31,7 \\
& 5 yll ve üzeri & 31 & 10,9 \\
& Toplam & 284 & 100,0 \\
\hline
\end{tabular}

Tablo 1'de görüldüğü üzere çalışmaya katılan 284 öğretmenin 183'ü $(\% 64,4)$ kadın, 101'i $(\% 35,6)$ erkektir. 90'1 (\%31,7) 31 yaş ve alt, 83'ü $(\% 29,2)$ 32-37 yaşında, 53'ü (\%18,7) 38-43 yaşında, 58'i (\%20,4) 44 yaş ve üzerindedir. 183'ü $(\% 64,4)$ kadın, 101'i $(\% 35,6)$ erkektir. 60'1 $(\% 21,1)$ ilkokul, 81'i (\%28,5) ortaokul, 143'ü (\%50,4) lise mezunudur. 225'i $(\% 79,2)$ lisans, 59'u (\%20,8) yüksek lisans mezunudur. 181'i (\%63,7) 1-5 yıl, 70'i $(\% 24,6)$ 6-10 yıl, 33'ü $(\% 11,6) 11$ yıl ve üzeri okulda çalı̧̧ma süresine sahiptir. 74'ü (\%26,1) 1 yıldan az, 89'u (\%31,3) 1-2 yıl, 90'ı (\%31,7) 3-4 yıl 31'i $(\% 10,9) 5$ yıl ve üzeri mevcut müdürle çalışmıştır.

\section{Veri Toplama Araçları}

Araştırmada veri toplamak amacıyla kişisel bilgi formu, kuantum liderlik ve yaratıcı düşünme eğilimi ölçekleri kullanılmıştır.

1. Aşamada araştırmada kullanılan Kişisel Bilgi Formu; çalışmaya katılan öğretmenlerin demografik özelliklerinin belirlenmesi için araştırmacının geliştirdiği soru formudur.

2. Aşamada okul yöneticilerinin kuantum liderlik düzeyini tespit etmek için kullanılan Erçetin, Potas, Açıkalın, Turan ve Bisaso (2016) tarafından geliştirilmiş olan "Okul Yöneticilerinin Kuantum 
Liderlik Davranışları Ölçeği" uygulanmıştır. Ölçek 4 boyut ve toplam 38 maddeden oluşmaktadır. Ölçeğin güvenirlik katsayısı ilişkin birinci boyutu. 97, ikinci boyutu. 96, üçüncü boyutu. 96 ve dördüncü boyutu. 95 değerindedir. Ölçeğin tamamı için güvenirlik katsayısı ise. 98 olarak bulunmuştur. Bulunan bu değerler, ölçeğin tamamının ve alt boyutlarının güvenilir olduğunu göstermektedir.

3. Aşamada ise öğretmenlerin yaratıcı düşünme eğilimlerini belirlemeye yönelik olarak Özgenel ve Çetin (2017) tarafından geliştirilmiş olan "Yaratıcı Düşünme Eğilimi Ölçeği" kullanılmıştır. Ölçek 25 sorudan ve 6 faktörden oluşmaktadır. Ölçeğin genel güvenirlik katsayısı $0.87^{\prime}$ dir.

\section{Verilerin Toplanması}

Araştırmanın amaç ve yöntemi belirlendikten sonra ölçeklerin kullanım izni alınmış örneklem grubunu oluşturan öğretmenlere ulaşmak için internet portalı kullanılmış ve veriler internet ortamında araştırmaya gönüllü katılan öğretmenlerden toplanmıştır.

\section{Verilerin Analizi}

Veriler toplandıktan sonra veri kontrolü yapılmış, hatalı girilen formlar çıkarılmış yeterli dağılımın oluşmadığı demografik dağılımlar gruplandırılmış ve ölçeklerin analizi SPSS 21 programı ile gerçekleştirilmiştir. Öncelikli olarak demografik bilgiler için frekans ve yüzde analizi yapılmıştır. Ardından ölçeklerin aritmetik ortalaması ve standart sapmaları hesaplanmıştır. Gruplar ile ölçek puanları arasında anlamlı farklılık olup olmadığını anlamak için $t$ testi, ANOVA ve Scheffe testi uygulanmıştır. Ayrıca kuantum liderlik ile yaratıcı düşünme eğilimi düzeyi arasındaki ilişki için pearson korelasyon analizi kullanılmıştır.

\section{Bulgular}

Araştırma bulgularına göre okul yöneticileri, çoğu zaman kuantum liderlik özelliği göstermektedirler. Tablo 2'de görüldüğü üzere, 
öğretmenlerin görüşlerine göre "Okul Yöneticilerinin Kuantum Liderlik Davranışları" ölçeğinin toplam puanların ortalamaları 3,57 olarak tespit edilmiştir. Alt boyut ortalamaları en yüksekten en düşüğe doğru; "Liderlik, Lider-İzleyenler İkileminde Bir Etkileşim Alanıdır, Liderlik Olgusunun Kesikliliği, Liderliğin Etkisi Etkileşime Dayalıdır ve Liderlik Yapılandırılamaz ve Kestirilemez" şeklinde sıralanmaktadır.

Tablo 2. Kuantum Liderlik Davranışları Ölçeğinin Toplam Puanları ve Tüm Alt Boyutlarının Aritmetik Ortalama, Standart Sapma Değerleri

\begin{tabular}{llll}
\hline Boyut & $\mathbf{N}$ & $\overline{\mathbf{X}}$ & Ss \\
\hline Liderlik, Lider-İzleyenler İkileminde Bir Etkileşim Alanıdır & 284 & 3,70 & 8,35 \\
Liderlik Yapılandırılamaz ve Kestirilemez & 284 & 3,38 & 8,96 \\
Liderlik Olgusunun Kesikliliği & 284 & 3,63 & 9,76 \\
Liderliğin Etkisi Etkileşime Dayalıdır & 284 & 3,56 & 9,43 \\
Tüm Ölçek & $\mathbf{2 8 4}$ & $\mathbf{3 , 5 7}$ & $\mathbf{3 4 , 5 9}$ \\
\hline
\end{tabular}

\section{"Okul Yöneticilerinin Kuantum Liderlik Davranışları Ölçeği”} puanlarının cinsiyete göre anlamlı bir farklılaşma gösterip göstermediğini tespit etmek için yapılmış olan bağımsız grup $t$ testi analizlerine göre grupların aritmetik ortalamaları arasında toplam ölçekle hiçbir alt boyutunda anlamlı bir farklılığa ( $\mathrm{p}>.05)$ rastlanmamıştır.

Yaş değişkeni ile okul yöneticilerinin kuantum liderlik düzeyleri arasında ölçeğin tamamında ve hiçbir alt boyutta anlamlı bir farklılaşma ( $p>.05)$ tespit edilememiştir.

“Okul Yöneticilerinin Kuantum Liderlik Davranışları Ölçeği” puanları öğretmenlerin çalıştıkları okul kademesine göre hiçbir alt boyutta ve genel ölçekte (p> .05) farklılaşmamaktadır.

“Okul Yöneticilerinin Kuantum Liderlik Davranışları Ölçeği” puanları öğretmenlerin mezuniyetlerine göre hiçbir alt boyutta ve tüm ölçekte anlamlı şekilde ( $\mathrm{p}>$.05) farklılaşmamaktadır.

Yapılan ANOVA analizlerine göre okul yöneticilerinin kuantum liderlik düzeyinin öğretmenlerin okuldaki çalışma süresine göre toplam ölçek ve hiçbir alt boyutta anlamlı şekilde farklılaşmadığı $(p>.05)$ anlaşılmaktadır.

Okul yöneticilerinin kuantum liderlik düzeyinin öğretmenlerin okul müdürü ile çalışma süresi değişkenine göre ölçeğin ortalaması ve hiçbir alt boyutunda anlamlı şekilde ( $\mathrm{p}>$.05) farklılaşmamaktadır. 
Araştırmada "Öğretmenlerin Yaratıcı Düşünme Eğilimleri Ölçeğinin" ortalaması " 4,13 " olarak bulunurken; alt boyutlarının ortalaması en büyükten küçüğe doğru şüphe etme, esneklik, merak, yenilik arama, öz disiplin ve cesaret şeklindedir. İlgili tespitler Tablo 3'de yer almaktadır.

Tablo 3. Öğretmenlerin Yaratıcı Düşünme Eğilimleri Ölçeğinin Toplam Puanları Ve Tüm Alt Boyutlarının Aritmetik Ortalama, Standart Sapma Değerleri

\begin{tabular}{llll}
\hline Boyut & N & $\overline{\mathbf{X}}$ & Ss \\
\hline Öz disiplin & 284 & 4,06 & 2,201 \\
Yenilik Arama & 284 & 4,12 & 4,213 \\
Cesaret & 284 & 3,94 & 2,508 \\
Merak & 284 & 4,29 & 1,590 \\
Şüphe Etme & 284 & 4,32 & 1.167 \\
Esneklik & 284 & 4,30 & 1,566 \\
Tüm ölçek & $\mathbf{2 8 4}$ & $\mathbf{4 , 1 3}$ & $\mathbf{4 , 1 3}$ \\
\hline
\end{tabular}

Öğretmenlerin "Yaratıcı Düşünme Eğilimleri Ölçeği" cinsiyete göre hiçbir alt boyutta anlamlı şekilde ( $\mathrm{p}>$.05) farklılaşmamaktadır.

Öğretmenlerin "Yaratıcı Düşünme Eğilimleri Ölçeği" puanları yaşa göre hiçbir alt boyutta anlamlı şekilde (p> .05) farklılaşmamaktadır.

Öğretmenlerin Yaratıcı Düşünme Eğilimleri Ölçeği puanlarının okul kademesine göre yenilik arama, cesaret ve esneklik alt boyutlarında anlamlı şekilde farklılaştığ görülürken, diğer alt boyutlarda anlamlı bir farklılık bulunamamıştır. Hangi gruplarda anlamlı farklılığın olduğunu bulmak için Scheffe testi yapılmıştır ve test sonuçları Tablo 4 ve Tablo 4.1' de görülmektedir.

Tablo 4. Öğretmenlerin Yaratıcı Düşünme Eğilimleri Ölçeği Puanlarının Öğretmenlerin Çalıştıkları Okul Kademesine Göre Anova Testi

\begin{tabular}{|c|c|c|c|c|c|c|c|c|c|c|}
\hline \multicolumn{5}{|c|}{$f, \mathrm{x}$ ve ss Değerleri } & \multicolumn{6}{|c|}{ ANOVA Sonuçları } \\
\hline Puan & Gruplar & $\mathbf{N}$ & $\bar{X}$ & ss & Var. K. & KT & $S d$ & $K O$ & $\mathbf{F}$ & $P$ \\
\hline \multirow{5}{*}{ Öz disiplin } & İlkokul & 60 & 4,12 & 2,042 & G. Aras1 & 30,022 & 2 & 15,011 & 2,074 & ,128 \\
\hline & Ortaokul & 81 & 3,96 & 2,506 & G. İçi & 2033,820 & 281 & 7,238 & & \\
\hline & Lise & 143 & 4,09 & 3,009 & Toplam & 2063,842 & 283 & & & \\
\hline & Toplam & 284 & 4,06 & 2,701 & & & & & & \\
\hline & İlkokul & 60 & 4,23 & 3,610 & G. Aras1 & 128,378 & 2 & 64,189 & 3,685 & ,026 \\
\hline \multirow{3}{*}{$\begin{array}{l}\text { Yenilik } \\
\text { Arama }\end{array}$} & Ortaokul & 81 & 4,00 & 4,367 & G. İçi & 4894,590 & 281 & 17,418 & & \\
\hline & Lise & 143 & 4,15 & 4,279 & Toplam & 5022,968 & 283 & & & \\
\hline & Toplam & 284 & 4,12 & 4,213 & & & & & & \\
\hline \multirow{4}{*}{ Cesaret } & İlkokul & 60 & 4,02 & 2,222 & G. Aras1 & 88,574 & 2 & 44,287 & 7,359 & ,001 \\
\hline & Ortaokul & 81 & 3,72 & 2,643 & G. İçi & 1691,144 & 281 & 6,018 & & \\
\hline & Lise & 143 & 4,03 & 2,434 & Toplam & 1779,718 & 283 & & & \\
\hline & Toplam & 284 & 3,94 & 2,508 & & & & & & \\
\hline
\end{tabular}




\begin{tabular}{lllllllllll}
\multirow{5}{*}{ Merak } & Illkokul & 60 & 4,39 & 1,440 & G. Arası & 7,333 & 2 & 3,667 & 1,455 & ,235 \\
& Ortaokul & 81 & 4,24 & 1,630 & G. İçi & 708,103 & 281 & 2,520 & & \\
& Lise & 143 & 4,28 & 1,621 & Toplam & 715,437 & 283 & & \\
\multirow{5}{*}{ Şüphe Etme } & Toplam & 284 & 4,29 & 1,590 & & & & & \\
& İlkokul & 60 & 4,38 & 1,140 & G. Arası & 2,498 & 2 & 1,249 &, 917 &, 401 \\
& Ortaokul & 81 & 4,25 & 1,097 & G. İçi & 382,868 & 281 & 1,363 & & \\
& Lise & 143 & 4,33 & 1,216 & Toplam & 385,366 & 283 & & \\
& Toplam & 284 & 4,32 & 1,167 & & & & & & \\
\multirow{5}{*}{ Esneklik } & Ilkokul & 60 & 4,37 & 1,316 & G. Arası & 15,045 & 2 & 7,523 & 3,112 &, 046 \\
& Ortaokul & 81 & 4,17 & 1,550 & G. İçi & 679,349 & 281 & 2,418 & & \\
& Lise & 143 & 4,29 & 1,647 & Toplam & 694,394 & 283 & & & \\
& Toplam & 284 & 4,29 & 1,566 & & & & & & \\
\hline
\end{tabular}

Tablo 4.1 Scheffe Testi Sonuçları

\begin{tabular}{|c|c|c|c|c|c|}
\hline Puan & Okul Kademesi & (i) Okul Kademesi (j) & $\bar{x}_{i}-\bar{x}_{j}$ & $\mathrm{Sh}_{\overline{\mathrm{x}}}$ & $p$ \\
\hline \multirow{6}{*}{ Yenilik Arama } & \multirow{2}{*}{ İlkokul } & Ortaokul & $1,842^{*}$ & 711 & ,036 \\
\hline & & Lise & 657 & 642 & ,593 \\
\hline & \multirow{2}{*}{ Ortaokul } & İlkokul & $-1,842^{*}$ & 711 & ,036 \\
\hline & & Lise & $-1,185$ & ,580 & , 126 \\
\hline & \multirow{2}{*}{ Lise } & İlkokul &,- 657 & 642 & ,593 \\
\hline & & Ortaokul & 1,185 &, 580 & ,126 \\
\hline \multirow{6}{*}{ Cesaret } & \multirow{2}{*}{ İlkokul } & Ortaokul & $1,223^{*}$ & ,418 & ,015 \\
\hline & & Lise &,- 019 & ,377 & ,999 \\
\hline & \multirow{2}{*}{ Ortaokul } & İlkokul & $-1,223^{*}$ & ,418 & ,015 \\
\hline & & Lise & $-1,242^{*}$ & ,341 & ,002 \\
\hline & \multirow{2}{*}{ Lise } & İlkokul & ,019 & ,377 & ,999 \\
\hline & & Ortaokul & $1,242^{*}$ & ,341 & , 002 \\
\hline \multirow{6}{*}{ Esneklik } & \multirow{2}{*}{ İlkokul } & Ortaokul & ,586 & 265 & ,048 \\
\hline & & Lise & 124 & 239 & ,875 \\
\hline & \multirow{2}{*}{ Ortaokul } & İlkokul &,- 586 & ,265 & ,048 \\
\hline & & Lise &,- 462 & ,216 & 104 \\
\hline & \multirow{2}{*}{ Lise } & İlkokul &,- 124 & 239 & 875 \\
\hline & & Ortaokul & ,462 & ,216 & 104 \\
\hline
\end{tabular}

Scheffe testi sonucunda, yenilik arama ve esneklik alt boyutunda ilkokulda çalışanlar ile ortaokulda çalışanların puanları arasında anlamlı farklılık olduğu ( $\mathrm{p}<$.05); ilkokulda çalışan öğretmenlerin daha yüksek yenilik arama puanına sahip olduğu görülmüştür. Cesaret alt boyutunda ortaokulda çalışanlar ile ilkokul ve lisede çalışanlar arasında anlamlı farklılık $(\mathrm{p}<.05)$ olduğu; ortaokulda çalışanların en düşük cesaret puanına sahip olduğu görülmüştür.

"Öğretmenlerin Yaratıcı Düşünme Eğilimleri Ölçeği" puanları mezuniyet değişkenine göre hiçbir alt boyutta anlamlı şekilde farklılaşmamaktadır. 
"Öğretmenlerin Yaratıcı Düşünme Eğilimleri Ölçeği" puanları okuldaki çalışma süresi değişkenine göre öz disiplin, yenilik arama, cesaret ve esneklik alt boyutlarında anlamlı şekilde farklılaşmaktadır. Öte yandan merak ve şüphe etme alt boyutlarında anlamlı bir farklılık tespit edilmemiştir. İlgili analiz sonuçları Tablo 5'de verilmiştir.

Tablo 5. Öğretmenlerin Yaratıcı Düşünme Eğilimleri Ölçeği Puanlarının Öğretmenlerin Okuldaki Çalışma Süresine Göre Anova Testi

\begin{tabular}{|c|c|c|c|c|c|c|c|c|c|c|}
\hline \multicolumn{5}{|c|}{$f, x$ ve ss Değerleri } & \multicolumn{6}{|c|}{ ANOVA Sonuçları } \\
\hline Puan & $\begin{array}{l}\text { Gruplar } \\
\left(Y_{1}\right)\end{array}$ & $\mathrm{N}$ & $\bar{X}$ & SS & Var.K. & $K T$ & $S d$ & KO & $\mathrm{F}$ & $P$ \\
\hline \multirow{4}{*}{$\begin{array}{l}\text { Öz } \\
\text { disiplin }\end{array}$} & $1-5$ & 181 & 4,03 & 2,634 & G. Arasi & 58,866 & 2 & 29,433 & 4,125 & ,017 \\
\hline & $6-10$ & 70 & 4,03 & 2,734 & G. İçi & 2004,976 & 281 & 7,135 & & \\
\hline & 11 ve üzeri & 33 & 4,31 & 2,739 & Toplam & 2063,842 & 283 & & & \\
\hline & Toplam & 284 & 4,06 & 2,701 & & & & & & \\
\hline \multirow{4}{*}{$\begin{array}{l}\text { Yenilik } \\
\text { Arama }\end{array}$} & $1-5$ & 181 & 4,10 & 4,155 & G. Arası & 174,513 & 2 & 87,257 & 5,057 & ,007 \\
\hline & $6-10$ & 70 & 4,05 & 4,296 & G. İçi & 4848,455 & 281 & 17,254 & & \\
\hline & 11 ve üzeri & 33 & 4,39 & 3,822 & Toplam & 5022,968 & 283 & & & \\
\hline & Toplam & 284 & 4,12 & 4,213 & & & & & & \\
\hline \multirow{4}{*}{ Cesaret } & $1-5$ & 181 & 3,90 & 2,455 & G. Arası & 57,519 & 2 & 28,759 & 4,692 & ,010 \\
\hline & $6-10$ & 70 & 3,89 & 2,646 & G. İçi & 1722,200 & 281 & 6,129 & & \\
\hline & 11 ve üzeri & 33 & 4,25 & 2,194 & Toplam & 1779,718 & 283 & & & \\
\hline & Toplam & 284 & 3,94 & 2,508 & & & & & & \\
\hline \multirow{4}{*}{ Merak } & $1-5$ & 181 & 4,27 & 1,583 & G. Arası & 6,078 & 2 & 3,039 & 1,204 & ,302 \\
\hline & $6-10$ & 70 & 4,26 & 1,614 & G. İçi & 709,359 & 281 & 2,524 & & \\
\hline & 11 ve üzeri & 33 & 4,42 & 1,567 & Toplam & 715,437 & 283 & & & \\
\hline & Toplam & 284 & 4,29 & 1,590 & & & & & & \\
\hline \multirow{4}{*}{$\begin{array}{l}\text { Şüphe } \\
\text { Etme }\end{array}$} & $1-5$ & 181 & 4,30 & 1,173 & G. Arası & 2,738 & 2 & 1,369 & 1,005 & ,367 \\
\hline & $6-10$ & 70 & 4,31 & 1,132 & G. İçi & 382,628 & 281 & 1,362 & & \\
\hline & 11 ve üzeri & 33 & 4,45 & 1,208 & Toplam & 385,366 & 283 & & & \\
\hline & Toplam & 284 & 4,32 & 1,167 & & & & & & \\
\hline \multirow{4}{*}{ Esneklik } & $1-5$ & 181 & 4,28 & 1,539 & G. Arası & 16,444 & 2 & 8,222 & 3,408 & ,034 \\
\hline & $6-10$ & 70 & 4,22 & 1,717 & G. İçi & 677,950 & 281 & 2,413 & & \\
\hline & 11 ve üzeri & 33 & 4,50 & 1,228 & Toplam & 694,394 & 283 & & & \\
\hline & Toplam & 284 & 4,29 & 1,566 & & & & & & \\
\hline
\end{tabular}


Anlamlı farklılı̆̆ın hangi grupların arasında olduğunun tespiti için Scheffe testi uygulanmış ve test sonuçları tablo 5.1 de görülmektedir.

Tablo 5.1. Scheffe Testi Sonuçları

\begin{tabular}{|c|c|c|c|c|c|}
\hline Puan & $\begin{array}{l}\text { Okulda Çalışma Süresi } \\
\text { (Yı1) }\end{array}$ & $\begin{array}{l}\text { (i) Okulda Çalışma } \\
\text { Süresi (j) }\end{array}$ & $\bar{x}_{i}-\bar{x}_{j}$ & $\mathrm{Sh}_{\overline{\mathrm{x}}}$ & $p$ \\
\hline \multirow{6}{*}{ Öz disiplin } & \multirow{2}{*}{$1-5$} & $6-10$ yıl &,- 022 & ,376 & ,998 \\
\hline & & 11 yıl ve üzeri & $-1,427^{*}$ &, 506 & ,020 \\
\hline & \multirow{2}{*}{$6-10$} & $1-5 \mathrm{yll}$ & ,022 & ,376 & ,998 \\
\hline & & 11 yıl ve üzeri & $-1,404^{*}$ &, 564 & ,047 \\
\hline & \multirow{2}{*}{11 ve üzeri } & $1-5$ yıl & $1,427^{*}$ &, 506 & 020 \\
\hline & & $6-10$ yıl & $1,404^{*}$ &, 564 & ,047 \\
\hline \multirow{6}{*}{ Yenilik Arama } & \multirow{2}{*}{$1-5$} & $6-10$ yıl & ,402 & ,585 & 789 \\
\hline & & 11 yıl ve üzeri & $-2,276^{*}$ & ,786 & ,016 \\
\hline & \multirow{2}{*}{$6-10$} & $1-5$ yıl &,- 402 &, 585 & ,789 \\
\hline & & 11 yıl ve üzeri & $-2,678^{*}$ &, 877 & ,010 \\
\hline & \multirow{2}{*}{11 ve üzeri } & $1-5$ yıl & $2,276^{*}$ & 786 & ,016 \\
\hline & & $6-10$ yıl & $2,678^{*}$ &, 877 &, 010 \\
\hline \multirow{6}{*}{ Cesaret } & \multirow{2}{*}{$1-5$} & $6-10$ yil & ,056 & ,348 & ,987 \\
\hline & & 11 yıl ve üzeri & $-1,387^{*}$ & 469 & ,013 \\
\hline & \multirow{2}{*}{$6-10$} & $1-5$ yıl &,- 056 & ,348 & ,987 \\
\hline & & 11 yıl ve üzeri & $-1,443^{*}$ &, 523 & ,023 \\
\hline & \multirow{2}{*}{11 ve üzeri } & $1-5 \mathrm{yll}$ & $1,387^{*}$ & 469 & ,013 \\
\hline & & $6-10$ yıl & $1,443^{*}$ &, 523 &, 023 \\
\hline \multirow{6}{*}{ Esneklik } & \multirow{2}{*}{$1-5$} & $6-10 \mathrm{yll}$ & ,185 & 219 & ,700 \\
\hline & & 11 yıl ve üzeri &,- 659 & 294 & ,083 \\
\hline & \multirow{2}{*}{$6-10$} & $1-5$ yil &,- 185 & 219 & ,700 \\
\hline & & 11 yıl ve üzeri &,$- 844^{*}$ & ,328 & , 038 \\
\hline & \multirow{2}{*}{11 ve üzeri } & $1-5$ yıl & 659 & ,294 & ,083 \\
\hline & & 6-10 yıl &, $844^{*}$ & ,328 & ,038 \\
\hline
\end{tabular}

Tablo 5.1 incelendiğinde "Öğretmenlerin Yaratıcı Düşünme Eğilimleri Ölçeği" puanlarının okuldaki çalışma süresi değişkenine göre öz disiplin, yenilik arama, cesaret ve esneklik alt boyutlarında okuldaki çalışma süresi 11 yıl ve üzeri olan grupla diğer gruplar arasında anlamlı bir farklılığın oluştuğu görülmektedir. Çalışma süresi 11 yıl ve üzeri olanların öz disiplin puanları daha yüksek bulunmuştur.

"Öğretmenlerin Yaratıcı Düşünme Eğilimleri Ölçeği" puanları okul müdürü ile çalışma süresine göre cesaret alt boyutunda anlamlı olarak farklılaşmaktadır. Diğer alt boyutlarda anlamlı farklılık tespit edilmemiştir. İlgili sonuç Tablo 6'da görülmektedir.

Tablo 6. Öğretmenlerin Yaratıcı Düşünme Eğilimleri Ölçeği Puanlarının Öğretmenlerin Okul Müdürü Ile Çalışma Süresine Göre Anova Testi

$f$, $x$ ve $s s$ Değerleri 


\begin{tabular}{|c|c|c|c|c|c|c|c|c|c|}
\hline Puan & $\begin{array}{l}\text { Gruplar } \\
\text { (Y1l) }\end{array}$ & $\mathbf{N}$ & $\bar{X}$ & ss & Var.K. & $K T$ & K & KO & $P$ \\
\hline \multirow{5}{*}{ Öz disiplin } & 1 yıldan az & 74 & 4,06 & 3,260 & G. Arası & 23,931 & 3 & 7,977 & ,352 \\
\hline & $1-2$ & 89 & 4,01 & 2,302 & G. İçi & 2039,910 & 280 & 7,285 & \\
\hline & $3-4$ & 90 & 4,06 & 2,774 & Toplam & 2063,842 & 283 & & \\
\hline & 5 ve üzeri & 31 & 4,22 & 1,938 & & & & & \\
\hline & Toplam & 284 & 4,06 & 2,701 & & & & & \\
\hline \multirow{5}{*}{$\begin{array}{l}\text { Yenilik } \\
\text { Arama }\end{array}$} & 1 yıldan az & 74 & 4,10 & 4,644 & G. Arası & 62,855 & 3 & 20,952 & 2,317 \\
\hline & $1-2$ & 89 & 4,05 & 4,098 & G. İçi & 4960,114 & 280 & 17,715 & \\
\hline & $3-4$ & 90 & 4,18 & 3,887 & Toplam & 5022,968 & 283 & & \\
\hline & 5 ve üzeri & 31 & 4,19 & 4,334 & & & & & \\
\hline & Toplam & 284 & 4,12 & 4,213 & & & & & \\
\hline \multirow{5}{*}{ Cesaret } & 1 yıldan az & 74 & 3,79 & 2,674 & G. Arası & 64,357 & 3 & 21,452 & 2,016 \\
\hline & $1-2$ & 89 & 3,91 & 2,340 & G. İçi & 1715,361 & 280 & 6,126 & \\
\hline & $3-4$ & 90 & 4,00 & 2,540 & Toplam & 1779,718 & 283 & & \\
\hline & 5 ve üzeri & 31 & 4,19 & 2,140 & & & & & \\
\hline & Toplam & 284 & 3,94 & 2,508 & & & & & \\
\hline \multirow{5}{*}{ Merak } & 1 yıldan az & 74 & 4,25 & 1,742 & G. Arası & 2,998 & 3 & ,999 & 758 \\
\hline & $1-2$ & 89 & 4,27 & 1,497 & G. İçi & 712,438 & 280 & 2,544 & \\
\hline & $3-4$ & 90 & 4,32 & 1,621 & Toplam & 715,437 & 283 & & \\
\hline & 5 ve üzeri & 31 & 4,35 & 1,413 & & & & & \\
\hline & Toplam & 284 & 4,29 & 1,590 & & & & & \\
\hline \multirow{5}{*}{ Şüphe Etme } & 1 yildan az & 74 & 4,38 & 1,280 & G. Arası & 3,429 & 3 & 1,143 & 474 \\
\hline & $1-2$ & 89 & 4,27 & 1,108 & G. İçi & 381,938 & 280 & 1,364 & \\
\hline & $3-4$ & 90 & 4,28 & 1,171 & Toplam & 385,366 & 283 & & \\
\hline & 5 ve üzeri & 31 & 4,42 & 1,036 & & & & & \\
\hline & Toplam & 284 & 4,32 & 1,167 & & & & & \\
\hline \multirow{5}{*}{ Esneklik } & 1 yildan az & 74 & 4,33 & 1,783 & G. Arası & 8,046 & 3 & 2,682 & ,352 \\
\hline & $1-2$ & 89 & 4,29 & 1,364 & G. İçi & 686,349 & 280 & 2,451 & \\
\hline & $3-4$ & 90 & 4,23 & 1,700 & Toplam & 694,394 & 283 & & \\
\hline & 5 ve üzeri & 31 & 4,41 & 1,055 & & & & & \\
\hline & Toplam & 284 & 4,29 & 1,566 & & & & & \\
\hline
\end{tabular}

Farklılaşmanın hangi grupların arasında olduğunun tespiti için Scheffe testi yapılmıştır ve test sonuçları tablo 6.1 de görülmektedir.

Tablo 6.1 Scheffe Testi Sonuçları

\begin{tabular}{|c|c|c|c|c|c|}
\hline Boyut & $\begin{array}{l}\text { Okul Müdürü İle } \\
\text { Çalışma Süresi (i) } \\
\text { (Yıl) }\end{array}$ & $\begin{array}{l}\text { Okul Müdür } \\
\text { Çalışma Süresi (j) } \\
\text { (Yıl) }\end{array}$ & $\overline{\boldsymbol{x}}_{\boldsymbol{i}}-\overline{\boldsymbol{x}}_{j}$ & $S h_{\bar{x}}$ & $p$ \\
\hline \multirow{12}{*}{ Cesaret } & \multirow{3}{*}{1 yıldan az } & $1-2$ &,- 501 & ,389 & 648 \\
\hline & & $3-4$ &,- 838 & 388 & 202 \\
\hline & & 5 ve üzeri & $-1,612^{*}$ & ,530 & 028 \\
\hline & \multirow{3}{*}{$1-2$} & 1 yıldan az &, 501 & 389 & 648 \\
\hline & & $3-4$ &,- 337 & ,370 &, 842 \\
\hline & & 5 ve üzeri & $-1,111$ & ,516 & ,203 \\
\hline & \multirow{3}{*}{$3-4$} & 1 yildan az & ,838 & 388 & 202 \\
\hline & & $1-2$ & ,337 & 370 & 842 \\
\hline & & 5 ve üzeri &,- 774 & ,515 &, 522 \\
\hline & \multirow{3}{*}{5 ve üzeri } & 1 ylddan az & $1,612^{*}$ & ,530 & ,028 \\
\hline & & $1-2$ & 1,111 & ,516 & 203 \\
\hline & & $3-4$ & ,774 & ,515 &, 522 \\
\hline
\end{tabular}


Tablo 6.1' de görüldüğü üzere "Öğretmenlerin Yaratıcı Düşünme Eğilimleri Ölçeği" puanlarının müdürle çalışma süresi değişkenine göre cesaret alt boyutunda okul müdürü ile çalışma süresi 1 yıldan az olanlar ile 5 yıl ve üzeri olanların arasında çalışma süresi 5 yıl ve üzerinde olanlar yönünde anlamlı şekilde farklılaşmaktadır.

Okul yöneticilerinin kuantum liderlik davranışları ile öğretmenlerin yaratıcı düşünme eğilimleri arasındaki ilişkinin belirlenmesi için pearson korelasyon analizi yapılarak; kuantum liderlik ölçeği toplam puanları ile yaratıcı düşünme eğiliminin öz disiplin, yenilik arama, şüphe etme ve esneklik alt boyutları arasında pozitif yönlü düşük düzeyde anlamlı ilişki olduğu $(\mathrm{p}<.05 ; \mathrm{r}<.3)$ cesaret ve merak etme alt boyutları ile anlamlı bir ilişki olmadığı (p>.05) tespit erdilmiştir. Ayrıca yaratıcı düşünme becerileri alt boyutlarının tümünün bir biri ile ilişkili olduğu görülmüştür. Analiz sonuçları Tablo 7'de görülmektedir.

Tablo 7. Kuantum Liderlik Ölçeği ile Öğretmenlerin Yaratıcı Düşünme Eğilimleri Ölçeği Arasındaki Korelâsyon Analizi Sonuçları

\begin{tabular}{|c|c|c|c|c|c|c|c|c|}
\hline & & $\begin{array}{l}\text { Liderlik } \\
\text { Ölçeği }\end{array}$ & Öz disiplin & $\begin{array}{l}\text { Yenilik } \\
\text { Arama }\end{array}$ & Cesaret & Merak & $\begin{array}{l}\text { Şüphe } \\
\text { Etme }\end{array}$ & Esneklik \\
\hline \multirow{3}{*}{ Liderlik Ölçeği } & $\mathrm{r}$ & 1 & $224^{* *}$ &, $215^{* *}$ & , 105 & 101 & ,170 & ,133" \\
\hline & $\mathrm{p}$ & & ,000 & ,000 & ,077 & ,090 & ,004 & ,025 \\
\hline & $\mathrm{n}$ & 284 & 284 & 284 & 284 & 284 & 284 & 284 \\
\hline \multirow{3}{*}{\multicolumn{2}{|c|}{ Öz disiplin }} &, $224^{* *}$ & 1 & $684^{* *}$ &, $524^{* *}$ &, $501^{* *}$ & $490^{* *}$ &, $580^{* *}$ \\
\hline & & ,000 & & 000 & 000 & 000 & 000 & 000 \\
\hline & & 284 & 284 & 284 & 284 & 284 & 284 & 284 \\
\hline \multirow{3}{*}{\multicolumn{2}{|c|}{ Yenilik Arama }} &, $215^{* *}$ & $684^{* *}$ & 1 & $646^{* *}$ &, $721^{* *}$ & $610^{* *}$ & $691^{* *}$ \\
\hline & & ,000 & ,000 & & ,000 & ,000 & ,000 & ,000 \\
\hline & & 284 & 284 & 284 & 284 & 284 & 284 & 284 \\
\hline \multirow{3}{*}{\multicolumn{2}{|c|}{ Cesaret }} & 105 &, $524^{* *}$ & $646^{* *}$ & 1 &, $502^{* *}$ & $447^{* *}$ &, $547^{* *}$ \\
\hline & & ,077 & ,000 & ,000 & & ,000 &, 000 & ,000 \\
\hline & & 284 & 284 & 284 & 284 & 284 & 284 & 284 \\
\hline \multirow{3}{*}{\multicolumn{2}{|c|}{ Merak }} & 101 &, $501^{* *}$ & $721^{* *}$ &, $502^{* *}$ & 1 &, $531^{* *}$ &, $548^{* *}$ \\
\hline & & ,090 & ,000 & 000 & ,000 & & 000 & 000 \\
\hline & & 284 & 284 & 284 & 284 & 284 & 284 & 284 \\
\hline \multirow{3}{*}{\multicolumn{2}{|c|}{ Şüphe Etme }} & $170^{* *}$ & $490^{* *}$ & $610^{* * *}$ & $447^{* *}$ &, $531^{* *}$ & 1 &, $583^{* *}$ \\
\hline & & ,004 & ,000 & ,000 &, 000 & ,000 & & ,000 \\
\hline & & 284 & 284 & 284 & 284 & 284 & 284 & 284 \\
\hline \multirow{3}{*}{ Esneklik } & $\mathrm{r}$ & $133^{*}$ &, $580^{* *}$ & $691^{* *}$ &, $547^{* *}$ &, $548^{* *}$ &, $583^{* *}$ & 1 \\
\hline & $\mathrm{p}$ & ,025 & 000 & ,000 & ,000 & ,000 & 000 & \\
\hline & $\mathrm{n}$ & 284 & 284 & 284 & 284 & 284 & 284 & 284 \\
\hline
\end{tabular}




\section{Sonuç ve Tartışma}

Okul yöneticilerinin kuantum liderlik düzeyleri $(X=3.57)$ ortalamayla "çoğu zaman" düzeyindedir. Araştırma sonuçları alan yazındaki çalışmalarla benzerlik göstermektedir (Turan, 2017; Turan ve Erçetin, 2017; Erçetin, Çevik ve Çelik, 2018; Tufan ve Korumaz, 2020). KaymanErtürk (2008) ise yaptığ çalışmada, öğretmen görüşlerine göre okul müdürlerinin kuantum liderlik davranışı düzeylerinin yüksek olduğu bulgusuna ulaşmıştır. Buna göre okul müdürlerinin yönetimde hiyarşiyi değil de ekip çalışmasını önemsediği, aşağıdan yukarıya örgütlenmeyi desteklediği ve kendi kendini örgütleyen bir çalışma ortamı yarattığ 1 anlaşılmaktadır.

Kuantum liderlik ölçeğinin alt boyutlara göre en yüksek puandan en düşük puana göre önem derecesi; “Liderlik, Lider-İzleyenler İkileminde Bir Etkileşim Alanıdır, Liderlik Olgusunun Kesikliliği, Liderliğin Etkisi Etkileşime Dayalıdır ve Liderlik Yapılandırılamaz ve Kestirilemez" şeklinde sıralanmaktadır. Buna göre okul müdürleri izleyenlerinden yani yönettiği örgütten kendilerini soyutlayamazlar. Okul müdürleri yönetimde onları izleyenlerin katılımını önemsemeliler ve okulun başarısının hep birlikte gerçekleştirilebileceği ortak bir örgüt kültürü oluşturmanın önemini bilmelidirler.

Okul yöneticilerinin kuantum liderlik davranışları öğretmenlerin cinsiyete göre hiçbir alt boyutta anlamlı bir farklılık oluşturmamaktadır. Araştırma sonuçları alan yazında Turan'ın (2017) araştırmasıyla benzerlik göstermektedir. Okul yöneticilerin kuantum liderlik davranışları araştırmaya katılan öğretmenlerin yaşına göre de hiçbir alt boyutta anlamlı bir farklılık oluşturmamaktadır. Cinsiyete ve yaşa göre anlamlı bir farklılık olmamasında okul müdürlerinin yönetimde holizm yani bütüncül bir anlayış benimsediği ile açıklanabilir.

Okul müdürlerinin kuantum liderlik davranışları öğretmenlerin çalıştıkları okul kademesi göre anlamlı bir farklılık oluşturmamaktadır. Bu sonuçtan farklı Erçetin, Çevik ve Çelik (2018) araştırmalarında ortaokulda görev yapan öğretmenlerin "Liderlik Yapılandırılamaz ve Kestirilemez" boyutuyla ilgili görüşlerinde ilkokul öğretmenlerine göre anlamlı derecede düşük çıktığı tespit edilmiştir. Okul müdürünün çalışanlarla etkileşimi ile birlikte belirsizliklerin azaltılması ve olasılıkların 
görünürlüğünün artırılması araştırma sonucumuzun çıkmasında etkili olmuştur.

Okul müdürlerinin kuantum liderlik davranışları öğretmenlerin mezuniyetine göre ölçeğin tüm alt boyutlarında benzer ve anlamlı bir farklılık oluşturmamaktadır. Bu sonuç Ertürk Kayman (2008) ve Turan (2017) 'ın çalışmalarından farklılık göstermektedir. Okul müdürlerinin kuantum liderlik davranışları; Ertürk Kayman (2008)'in tespitine göre öğretmenlerin eğitim durumuna bağlı olarak artmıştır. Turan (2017)' nın yaptığ1 çalışmada ise lisans mezunu öğretmenlerin görüşlerinin lisansüstü ve ön lisans mezunlarına göre anlamlı olarak yüksek çıktığ 1 görülmüştür.

Okul müdürlerinin kuantum liderlik davranışları öğretmenlerin okulda görev sürelerine göre anlamlı bir farklılık oluşturmamaktadır. Ölçeğin tüm alt boyutlarında benzer ve toplam çalışma sürelerine göre değişmediği görülmektedir. Araştırmanın bu sonucu Ertürk Kayman (2008) ve Turan' nın (2017) çalışma sonuçlarıyla benzerdir. Bu sonuç farklı çalışma sürelerine sahip öğretmenler için okul yönetimi tarafından etkili bir okul iklimi yaratıldığı sonucuna varılabilir.

Okul müdürlerinin kuantum liderlik davranışları öğretmenlerin okul müdürleri ile çalışma sürelerine göre anlamlı bir farklılık oluşturmamaktadır. Okul müdürlerinin kuantum liderlik davranışları ölçeğin tüm alt boyutlarında benzerdir ve öğretmenlerin okul müdürleri ile çalışma sürelerine göre değişmediği görülmektedir. Bu durum Turan'nın (2017) araştırma sonuçlarıyla benzerlik göstermektedir. Araştırma sonucu, okul müdürlerin kuantum liderlik davranışları açısından izleyenleri ile pozitif etkileşim ve iletişimde olduğu şeklinde yorumlanabilir.

Öğretmenlerin yaratıcı düşünme eğilimleri $(X=4,13)$ ortalamayla "genellikle" düzeyindedir. Yaratıcı düşünme becerileri alt boyutlarının tümünün bir biri ile ilişkili olduğu görülmüştür. Araştırmanın bu sonucu Yıldız ve vd (2011), Aydoğdu ve Yüksel (2013), Çoban (2016), Özgenel ve Çetin (2017)' nin yaptıkları araştırma sonuçlarıyla benzerlik göstermektedir. Bu sonuçlar 21. Yüzyıl yeterlikleri arasında gösterilen yaratıcı düşünme becerileri bakımından olumlu olarak değerlendirilmiştir. 
Öğretmenlerin yaratıcı düşünme eğilimleri cinsiyet, yaş, mezuniyet değişkenlerine göre anlamlı bir farklılık göstermemektedir. Araştırma sonucuyla benzer şekilde Meral ve Şahin (2019), yaratıcı düşünme eğilimleri ile yaş, mezun olunan bölüm, mesleki kıdem arasında anlamlı bir fark olmadığını tespit etmiştir. Çoban (2016) da öğretmenlerin yaşı ile yaratıcıkları arasında anlamlı fark olmadığını belirtmiştir. Araştırmamız sonuçlarından farklı olarak Durnacı ve Ültay (2020) yaptıkları araştırmada cinsiyet değişkenine göre kadın öğretmen adaylarının yaratıcı düşünme puan ortalamaları erkeklere göre yüksek çıkmıştır.

Öğretmenlerin yaratıcı düşünme eğilimleri çalıştıkları okul kademesi değişkenine göre yenilik arama, cesaret, esneklik alt boyutlarında anlamlı şekilde farklılaşırken diğer alt boyutlarda anlamlı bir farklılık bulunamamıştır. Yenilik arama ve esneklik alt boyutunda ilkokulda çalışan öğretmenlerin daha yüksek yenilik arama puanına sahip olduğu görülmüştür. Ortaokulda çalışanların en düşük cesaret puanına sahip olduğu görülmüştür. Kozikoğlu (2017)'nun yaptığı çalışmada ideal öğretmenlikte öne çıkan faktörlerden birisi olan yenilikçiliğin önemli olması araştırma sonuçlarımızla benzerlik göstermektedir. İlkokulda çalışan öğretmenlerin yenilikçilik ve esneklik puanlarının daha yüksek çıkması temel eğitimin bu seviyede verilmesi ve öğrencilerin öğrenmeleri arasında anlamlı ilişkilerin kurdurulması ve öğretmenlerimizin farklı öğretim yöntem ve teknikleri kullanması açısından açıklanabilir. Ayrıca yaratıcı olan öğretmenlerin öğrencileri de yaratıcı düşünme stillerine sahip olmaları açısından ilkokul kademesi önemli görülmektedir.

Öğretmenlerin Yaratıcı Düşünme Eğilimleri Ölçeği puanlarının okuldaki çalışma süresi değişkenine göre öz disiplin, yenilik arama, cesaret ve esneklik alt boyutlarında anlamlı bir farklılık bulunurken diğer alt boyutta anlamlı bir farklılık bulunmamıştır. Öz disiplin, yenilik arama, cesaret ve esneklik alt boyutlarında okuldaki çalışma süresi çalışma süresi 11 yıl ve üzeri olanların öz disiplin puanları daha yüksek bulunmuştur. Çalışmamız sonuçlarından farklı olarak Başaran ve Keleş (2015) ve Kılıç (2015)'in yaptıkları çalışmalarda öğretmenlerin yenilikçilik özelliği mesleki deneyime göre anlamlı farklılık göstermemektedir. Araştırma sonuçlarımızla benzer şekilde Kozikoğlu ve Küçük (2020) yaptığ 1 çalışmada 16 yıldan fazla mesleki deneyime sahip öğretmenlerin daha yüksek düzeyde yenilikçilik özelliğine sahip olduğu tespit edilmiştir. 
Araştırmamızda okuldaki çalışma süresi çalışma süresi 11 yıl ve üzeri olanların öz disiplin puanları daha yüksek bulunmasını nedeni mesleki deneyim ve kariyer evrelerinden kaynaklı olduğunu düşündürmektedir.

Öğretmenlerin Yaratıcı Düşünme Eğilimleri Ölçeği puanlarının okul müdürü ile çalışma süresi değişkenine cesaret alt boyutunda anlamlı bir farklılık bulunurken diğer alt boyutta anlamlı bir farklılık bulunamamıştır. Okul müdürü ile çalışma süresi 5 yıl ve üzeri olanların cesaret puanları daha yüksek bulunmuştur. Bu durum deneyim ve tecrübenin artmasıyla cesaretin artması arasındaki pozitif yönlü bir ilişki olarak açıklanabilir.

Kuantum Liderlik Ölçeği ile Öğretmenlerin Yaratıcı Düşünme Eğilimleri Ölçeği arasındaki ilişkinin tespiti için pearson korelasyon analizi yapılmıştır ve kuantum liderlik ölçeği puanları ile öz disiplin, yenilik arama, şüphe etme ve esneklik alt boyutlarında pozitif yönlü anlamlı bir ilişki olduğu cesaret ve merak etme alt boyutlarında anlamlı bir ilişki olmadığı görülmüştür.

\section{Öneriler}

Eğitim örgütlerinin açık sistem özelliğine sahip olmaları yapısındaki karmaşıklığı arttırmaktadır. Okullardaki yaratıcı düşünme eğilimleri desteklenerek örgütün kaotik durumlardan çıkması ve belirsizliklerin fırsata dönüştürmesi için kuantum liderlik bir yol gösterici olarak önerilebilir. Kuantum liderlik yeni dünya düzeninde okul yöneticilerine, olasılıkları hesaba katan, bütüncül, sürekliliği esas alan ve etkileşime dayalı bir liderlik olarak önerebilir. Ayrıca öğretmenlerin yaratıcı düşünme eğilimlerinin arttırılması için okul müdürlerinin kuantum liderlik davranışları göstermeleri önemlidir. Buna göre okul yöneticilerinin öğretmenlerin yaratıcı düşünmeleri için fırsatlar yaratması ve destekleyici bir örgüt kültürü oluşturmaları önemlidir. Kuantum liderlik davranışlarını daha yoğun sergilemelerine uygun bir örgüt yapısı oluşturulması önerilebilir.

Ortaokulda görev yapan okul müdürleri, öğretmenlerinin yaratıcı düşünme eğilimlerini arttırmak adına onlarla küçük gruplar halinde toplantılar yaparak, yeni fikirler öne sürmeleri doğrultusunda onları cesaretlendirebilirler. 
Aynı okulda 11 yıldan fazla görev yapan öğretmenlerin kendi zümrelerindeki kıdemi az olan öğretmenlere mentorluk yapmaları öz disiplinlerini artırmalarını sağlayarak yaratıcı düşünme eğilimlerini besleyebilir.

Okul müdürleri çalışmaya yeni başladıkları öğretmenlerini yeni fikirler ve ürünler geliştirme konusunda desteklemelidirler. Okulda kıdemli ve yeni öğretmenlerin harmanlanmasıyla oluşturulacak çalışma grupları genel olarak yaratıcı düşünmeyi arttırarak okul gelişimine katkı sağlayabilir. 


\title{
EXTENDED ABSTRACT
}

\section{Investigation of the Relationship between School Administrators' Quantum Leadership Behaviors and Teachers' Creative Thinking Tendencies}

\author{
Münevver Çetin - Hilal Gürkan \\ Marmara University
}

\section{Introduction and Research Questions \& Purpose:}

The fact that educational organizations have an open system feature increases the complexity in their structure. Quantum leadership is considered important for the organization to get out of chaotic situations and turn uncertainties into opportunities by supporting creative thinking tendencies in schools.

Considering that quantum leadership behaviors, which bring a new and different understanding to management science, may have effects on the creative thinking tendencies of the organization, this research is conducted to find out the relations between these concepts in particular educational organizations.

The purpose of this research is to determine the "relationships between school administrators' quantum leadership behaviors and teachers' creative thinking tendencies, according to teachers' views".

In this direction, answers to the following questions were sought:

1. What is the quantum leadership behavior of school administrators?

2. According to teachers' opinions, do school administrators' quantum leadership behaviors differ significantly according to teachers' gender, age, type of school they work at, seniority, current school principal and working time?

3. What level are the creative thinking tendencies of the teachers?

4. Do teachers' creative thinking disposition levels differ significantly according to teachers' gender, age, type of school they work at, seniority, current school principal and working time? 
5. Is there a significant relationship between school administrators' quantum leadership levels and teachers' creative thinking tendencies?

Literature Review: Educational organizations are complex systems (Dean, 1995). This complexity is also valid in terms of purposes, resources, related factors and relations between preschool, primary, secondary and higher education institutions. In this respect, it is thought that organizational learning will emerge as a concept that can contribute greatly to the formation of future educational institutions and other organizational structures in quantum organizations that include behaviors with a natural organizational spirit (Yavaş and Polat, 2013).

Complexity reveals the need for a flexible and interactive leader in chaotic situations and situations where uncertainty is felt intensely. Flexibility is the ability of organizational managers to stretch their previous decisions from time to time in the face of change. Because organizations cannot always be governed by certain rules. Theories and practices are not specifically designed to be flexible according to the requirements of time and situation. Because the rapid change in the environment brings acceleration and change in processes (Keskinkılıç Kara, 2013)

Today, organizations have to put forward original ideas in order to gain competitive advantage and maintain their existence. However, they can keep up with the new world order with designs triggered by new and different ideas. This will be achieved by individuals with creative thinking disposition and creative thinking (Burkus, 2014; Özgenel \& Çetin, 2017).

\section{Methodology}

Relational screening model was used in the research. In 2018-2019 academic year, 284 teachers selected by simple random sampling method from approximately 1200 teachers working in various levels and branches at public schools in Beykoz/İstanbul participated in the study. Personal information form, quantum leadership and creative thinking disposition scales were used to collect data in the research. The data were collected from the teachers who voluntarily participated in the research via the internet. 
The analysis of the scales was carried out with the SPSS 21 program. First of all, frequency and percentage analyze were done to get demographic information. Then, the arithmetic mean and standard deviation of the scales were calculated. In order to understand whether there is a significant difference between the groups and the scale scores, T-test, ANOVA and Scheffe Tests were applied. In addition, Pearson Correlation Analysis was used to find out the relationship between quantum leadership and the level of creative thinking disposition.

\section{Results and Conclusions}

In the findings of the research, school administrators often show quantum leadership behavior. Quantum leadership behaviors of school administrators do not show a significant difference according to the variables of teachers' gender, age, school level they work at, graduation, working time at school, and working time with school principals. Teachers generally tend to think creatively. Significant positive relationships were found between quantum leadership and some dimensions of creative thinking dispositions. Quantum leadership can be suggested as a guide for the organization to get out of chaotic situations and transform uncertainties into opportunities by supporting teachers' creative thinking dispositions.

It is important for school principals to show quantum leadership behaviors in order to increase teachers' creative thinking tendencies. Accordingly, it is important for school administrators to create opportunities for teachers to think creatively and to create a supportive organizational culture. It can be suggested to create an organizational structure suitable for more intense display of quantum leadership behaviors.

\section{Kaynakça/References}

Aydoğdu, N. ve Yüksel, İ. (2013). The relationship between prospective mathematics teachers' beliefs and attitudes towards history of mathematics and their creativeness level. Journal of Research in Education and Teaching, 2(4), 186-194. 
Başaran, S. D. ve Keleş, S. (2015). Who is innovative? Examination of teachers' innovativeness level. Hacettepe University Journal of Education, 30(4), 106-118.

Burkus, D. (2014). The myths of creativity. San Francisco: Published by JosseyBass.

Clampitt, P. G., Williams, M. L. ve Korenak, A. (2000). Managing organizational uncertainty: Conceptualization and measurement. In international, communication, association conference.

Çoban, Ç. (2016). Okul öncesi öğretmenlerinin yaratıcılık düzeylerinin incelenmesi (Yayımlanmamış yüksek lisans tezi). Dumlupınar Üniversitesi, Uşak.

Dean, J. (1995). Managing the primary school. (2nd ed.). New York: Routledge.

Deardorff, D. S. ve Williams, G. (2006). Synergy leadership in quantum organizations. New York: Fesserdorff

Deming, W. E. (1996). Krizden çıkış (Çev.: C. Akaş). İstanbul: Arçelik.

Doğan, N. (2016). Creative thinking and creativity. Pegem Citation Index, 5, 167198.

Durnacı, Ü. ve Ültay, N. (2020). Sınıf öğretmeni adaylarının eleştirel ve yaratıcı düşünme eğilimleri. Turkish Journal of Primary Education, 5(2), 75-97.

Erçetin, Ş. Ş. (1999). Kuantum liderlik paradigması ile eğitim liderliğinin açıklanması. Cumhuriyet Döneminde Eğitim II, Talim ve Terbiye Dairesi. Ankara: MEB Yayinevi.

Erçetin, Ş. Ş. (2000). Lider sarmalında vizyon (2. baskı). Ankara: Nobel Yayın Dağıtım.

Erçetin, Ş. Ş. (2001 ). Yönetimde yeni yaklaşımlar. Ankara: Nobel Yayın.

Erçetin, Ş. Ş., Potas, N., Açıkalın Ş. N., Turan, S. ve Bisaso, S.M. (2016). A Study for Developing a Viable Quantum Leadership Scale. In ICPESS (International Congress on Politic, Economic and Social Studies) (No. 3).

Erçetin, Ş. Ş., Çevik, M. S. ve Çelik, M. (2018). Okul müdürlerinin kuantum liderlik davranışlarını gerçekleştirme düzeyleri. Uluslararası Liderlik Çalışmaları Dergisi: Kuram ve Uygulama, 1(2), 109-124.

Ertürk Kayman, E.(2008). Türkiye'deki Mesleki Eğitimin Güçlendirilmesi Projesi (MEGEP) içindeki yaygınlaştırıcı okul yöneticilerinin kuantum liderlik davranışların gerçekleştirme düzeyleri. Yüksek Lisans Tezi. Hacettepe Üniversitesi, Sosyal Bilimler Enstitüsü, Ankara.

Fullan, M. (2001). Leading in a culture of change. San Francisco, CA: Jossey-Bass. Karasar, N. (2007). Bilimsel araştırma yöntemi. İzmir: Nobel Yayınevi. 
Kayman, E. A. ve Erçetin, Ş. Ş. (2011).The level of the trained school principals' fullfillment of quantum leadership behaviors with strengthening vocational education and training (SVET) project in Turkey. Humanity E Social Sciences Journal, 6(1),16-21.

Keskinkılıç Kara, S. B. (2013).Yeni bilim ve liderlik. Akademik Bakış Dergisi, 34, 4. Kılıçer, K. ve Odabaşı, H. F. (2010). Individual innovativeness scale (IS): The study of adaptation to Turkish, validity and reliability. Hacettepe University Journal of Education, 38(38), 150-164.

Korucu, A. T. ve Olpak, Y. Z. (2015). Examination of teacher candidates' individual innovativeness properties from the different variables. Educational Technology: Thaeory and Practice, 5(1), 11- 127.

Korumaz, M. ve Tufan, M.(2020). Ortaokul yöneticilerinin kuantum liderlik davranışları ile öğretmenlerin inisiyatif alma düzeyleri arasındaki ilişkinin incelenmesi. Anemon Muş Alparslan Üniversitesi Sosyal Bilimler Dergisi, 8(3), 727-742.

Kozikoglu, İ. (2017). Prospective teachers' cognitive constructs concerning ideal teacher qualifications: A phenomenological analysis based on repertory grid technique. International Journal of Instruction, 10(3), 63-78.

Kozikoğlu, İ. ve Küçük, B. A. (2020). the investigation of the relationship between teachers' creative thinking tendencies and individual innovativeness characteristics. Journal of Education and Future, 17, 25-37.

Mansfield, D. (2003). Complexity theory and educational leadership. Nottingham: National College for School Leadership.

Orhon, G. (2014). Yaratıcılı: Nörofizyolojik, felsefi ve eğitsel temeller. Ankara: Pegem.

Overman, E. S. (1996). The new sciences of administration: Chaos and quantum theory. Public Administration Review, 56(5), 487-491.

Özgenel, M. ve Çetin, M. (2017). Marmara yaratıcı düşünme eğilimleri ölçeğinin geliştirilmesi: Geçerlik ve güvenirlik çalışması Marmara Üniversitesi Atatürk Ĕ̆itim Fakültesi Eğitim Bilimleri Dergisi, 46, 113-132. DOI: 10.15285/maruaebd.335087.

Meral, S. E. ve Şahin, F. T.(2019). Okul öncesi öğretmenlerinin yaratıcı düşünme eğilimleri. OPUS Uluslararası Toplum Araştırmaları Dergisi, 13(19), 311331.

MEB (2018). T.C. Milli Eğitim Bakanlığı fen bilimleri dersi öğretim programı. https://mufredat.meb.gov.tr/Dosyalar/201812312311937- 
FEN\%20B\%C4\%BOL \%C4\%BOMLER\%C4\%B0\%20\%C3\%96\%C4\%9ER ET\%C4\%BOM\%20PROGRAMI2018.pdf. Erişim tarihi. 03.11.2018

Shelton, C. D. ve Darling, J. R. (2004). From chaos to order: Exploring new frontiers in conflict management. Organization Development Journal, 22(3), 22-39.

Şişman, M. ve Turan, S. (2002). Dünyada eğitim yöneticilerinin yetiştirilmesine ilişkin başlıca yönelimler ve Türkiye için çıkarılabilecek bazı sonuçlar. 21. Yüzyıl Ĕ̆itim Yöneticilerinin Yetiştirilmesi Sempozyumu'nda (16-17 Mayıs 2002) sunulan bildiri.

Tetenbaum, T. J. (1998). Shifting paradigms: From Newton to Chaos. Organizational Dynamics, 26(4), 21-32.

Turan, S. (2017). Okul yöneticilerinin kuantum liderlik davranışlarının örgütsel zekâ düzeyine etkisi (Zonguldak ili örneği). (Yayımlanmamış doktora tezi). Hacettepe Üniversitesi, Eğitim Bilimleri Enstitüsü, Ankara.

Turan, S. ve Erçetin, Ş. Ş. (2017).The effect of schoolmanagers' quantum leadership behaviors on thelevel of organizational intelligence. Turkish Studies International Periodical for the Languages, Literature and History of Turkish or Turkic, 12(6), 762-782.

Uzunçarşılı Soydaş, A. (2012). Halkla ilişkiler uygulamaları ve yönetim: Kuantum ve Kaos teorisi. İstanbul Üniversitesi İletişim Fakültesi Dergisi, 2(12), 657-672.

Wheatley, M. J. (2006). Leadership and the New Science: Discovering order in a chaotic world (3rd ed.). San Francisco: Berrett-Koehler Publishers.

Yavaş, T. ve Polat, M. (2013). Eğitimde örgütsel gelişme ve kuantum örgütler. 8. Ulusal Ĕ̆itim Yönetimi Kongresi - Bildiri Özetleri Kitabı. 74 - 76.

Yıldız, L., Zırhlığlu, G., Yalçınkaya, M. ve Güven, Ş. (2011). Creativity and problem solving skills of physical education teacher candidates. Yüzüncü Yul University Journal of Education Faculty, 8, 18-36.

\section{Kaynakça Bilgisi / Citation Information}

Çetin, M. ve Gürkan, H. (2021). Okul yöneticilerinin kuantum liderlik davranışları ve öğretmenlerin yaratıcı düşünme eğilimleri arasındaki ilişkinin incelenmesi. OPUS- Uluslararası Toplum Araştırmaları Dergisi, 18(44), 7693-7720. DOI: 10.26466/opus.886390. 